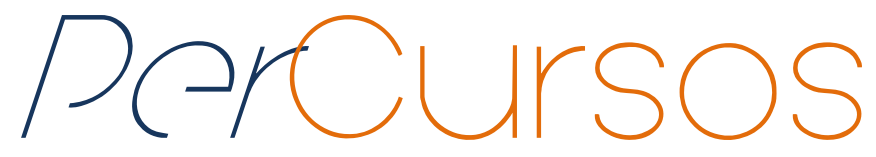

\title{
A iconografia bizantina do Período Medieval: percepções acerca das imagens religiosas para a pesquisa de História
}

\begin{abstract}
Resumo
Inquietações a respeito da cultura do Período Medieval levaram Jean-Claude Schmitt, Jean Pierre Vernant, Serge Gruzinski e Marc Augé a abordar os registros visuais em uma perspectiva antropológica, mesmo quando estas estivessem contíguas a temas tão caros à Historiografia. Este artigo objetiva compreender a cultura imagética bizantina do Período Medieval, para além do campo de conhecimento teologal, observando os ícones como fontes de pesquisa que problematizam temáticas tão caras à História. Para tanto, analisa o ícone da Өrotókoৎ (Mãe de Deus), procurando identificar para além das justificativas das formas, cores e composição da figura, o modo de os cristãos bizantinos perceberem-se em um tempo em que o religioso direcionava mentalidades, comportamentos e crenças. Cerca-se para isso, de autores que credenciam às imagens religiosas do Período Medieval a certificação de fontes plausíveis para a pertinente problematização historiográfica. Pensado como artefato documental e uma forma de representação, verifica-se como o ícone auxilia na compreensão dos comportamentos dos herdeiros da cultura religiosa bizantina (gregos e eslavos), imigrados para o Brasil, a partir da Proclamação da República e final das duas Grandes Guerras.
\end{abstract}

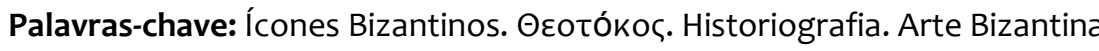

\author{
Paulo Augusto Tamanini \\ Doutor em História (UFSC) \\ Professor do Programa de Pós- \\ Graduação em Ensino (UFERSA) \\ paulo@tamanini.com.br
}

\section{Para citar este artigo: \\ TAMANINI, Paulo Augusto. A iconografia bizantina do Período Medieval: percepções acerca das imagens religiosas para a pesquisa de História. Revista PerCursos, Florianópolis, v. 19, n.40, p. 348 - 368 , maio/ago. 2018.}

\section{DOI: 10.5965/1984724619402018348}

http://dx.doi.org/10.5965/1984724619402018348 


\title{
The Byzantine iconography of the Medieval Period: perceptions about the religious images for the research of History
}

\begin{abstract}
Concerns about the culture of the Medieval Period led Jean-Claude Schmitt, Jean Pierre Vernant, Serge Gruzinski, and Marc Augé to address the visual records in an anthropological perspective, even when these were contiguous with themes so dear to Historiography. This article aims to understand the Byzantine imagery culture of the Medieval Period, beyond the field of theological knowledge, observing the images observing the icons as sources of research that problematize History. Therefore, it analyzes the icon of Erotókos (Mother of God) trying to identify beyond the justifications of the forms, colors and composition of the figure, a way Byzantine Christians to perceive in a while being to perceive himself at a time in which religion directed mentalities, behaviors and beliefs. This article is based on authors who accredited to the religious images of the Medieval Period the certification of plausible sources for the pertinent historiographic problematization. Thought as a documentary artifact and a form of representation, the icon helps to understand the behavior of the heirs of the Byzantine religious culture (Greek and Slavic), immigrated to Brazil, from the Proclamation of the Republic and the end of the two Great Wars.
\end{abstract}

Keywords: Byzantine Icons. Đeotókoৎ. Historiography. Byzantine Art 


\section{Introdução}

Abordar as novas epistemologias que cercam a arte visual, as formas narrativas e a cultura cristã oriental têm sido, para os historiadores do período Medieval, no Brasil, um grande desafio, dada a escassez e o pouco acesso às fontes imagéticas e a falta de traduções de obras originalmente escritas nos idiomas grego e russo. Na Europa Ocidental, contudo, a historicidade da iconografia oriental e as percepções do mundo Bizantino, em relação às pesquisas e escrita da História, desde o século XIX, têm se consolidado de forma progressiva, chamando a atenção de pesquisadores de vários países que se dedicam ao tema. Centros de formação e pesquisa, como o Institut Français d'Études Byzantines (Paris, França), o Hellenic Institute for Byzantine and Post-Byzantine Studies (Atenas, Grécia), a L'Associazione Italiana di Studi Bizantini (Veneza, Itália) e o Centre for Byzantine Research of Aristotle University of Thessaloniki (Tessalônica, Grécia), tornaram-se referências para os investigadores de várias partes da Europa, da América Latina e dos Estados Unidos da América.

Dentre esses, o Centro de Pesquisa Bizantina da Universidade Aristóteles de Tessalônica', fundado em 1966, por iniciativa de um grupo de Historiadores europeus medievalistas, é o mais proeminente, graças a permanente divulgação dos trabalhos desenvolvidos sobre a história das dinastias, culturas, religiosidades, arte popular e iconografia bizantina. Em consequência disso, tem sido considerado pela União Europeia, desde 1980, polo formal e catalisador de algumas coletâneas de livros e de ícones gregos, de fontes documentais escritas que deixam visibilizar a engenharia funcional dos primeiros séculos do Império Romano do Oriente. A influência do Centro de Pesquisa Bizantina da Universidade Aristóteles de Tessalônica tornou-se especialmente patente devido à capacidade de este firmar-se como rede agregadora dos grupos de pesquisa de diversos países da Europa, preocupados com temas que pudessem relacionar a imagem bizantina com as mentalidades e modos de viver de uma cultura fortemente alicerçada em valores religiosos. Para atender à demanda de investigadores e professores do Período Medieval, esse conjunto de instituições organiza, ainda hoje, minicursos,

\footnotetext{
${ }^{1}$ Centre for Byzantine Research of Aristotle University of Thessaloniki (Tradução nossa).
} 
seminários internacionais, reuniões acadêmicas e conferências que resultam em publicação em periódicos já consolidados.

Um desses periódicos editado pelo Centro de Pesquisa Bizantina da Universidade Aristóteles de Tessalônica é a Revista Bizantine, que reúne em seu corpo editorial historiadores, antropólogos, filósofos, linguistas e arqueólogos de várias nacionalidades, responsáveis pelo crivo e análise dos artigos. Ainda que o propósito da Revista Bizantine fosse a divulgação de trabalhos de cunho historiográfico, após 1990, os temas relacionados especificamente aos ícones religiosos começaram a ganhar mais espaço e frequência nas edições. Ficou perceptível que as imagens não eram apenas ilustrações, tinham um potencial investigativo a ser explorado, tornando-se necessário reformular o corpo editorial da revista para o atendimento dessa nova demanda.

Para dar início a essa pequena explanação, que relaciona a cultura visual com percepções do mundo bizantino, parte-se de uma noção antropológica, diversamente abordada pelos professores do Centro de Pesquisa Bizantina da Universidade Aristóteles

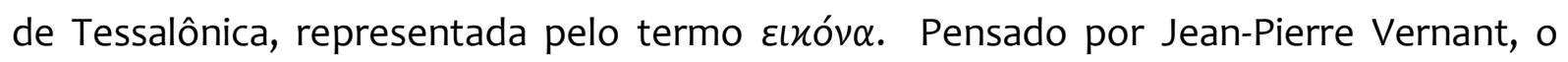
ícone ultrapassa o espaço de exposição e se estende àquilo que não se vê, mas se imagina e se acredita. Denominada de imagens mentais ou mnemônicas, a iconografia grega para Vernant é marcada por uma ruptura do pensamento grego na compreensão do conceito de imagem. A ruptura ocorreu por volta de 500 d.C., quando a língua grega usou, pela primeira vez, o termo $\varepsilon ı$ xóv $\alpha$ para designar uma imagem religiosa. O novo termo veio substituir, imediatamente, o termo $\varepsilon i ́ \delta \omega \lambda o$ (imagem, sonho, ídolo), que, a partir de então, passou a adotar uma significação negativa: cópia ou imitação inerte. Enquanto $\varepsilon(x o ́ v \alpha$ atraía a necessidade de definições ontológicas, o termo anterior servia apenas de parâmetro para a distinção filosófica entre 'aparência' e 'ser'. Sem a compreensão desta distinção ontológica, o estudo sobre as imagens religiosas ou sobre os ícones bizantinos tornar-se-ia impensável (VERNANT, 1990, p. 13). Desde então, a iconografia passou a ganhar um entendimento baseado em premissas não só da Teologia, como também de historiadores e antropólogos, cujo interesse havia sido despertado. Percebeu-se que, desde a feitura do ícone até sua exposição, existia um longo caminho, um conjunto de dados que poderia explicar a manifestação e consolidação da fé cristã vivida na corte 
bizantina. A partir desse novo foco investigativo, historiadores como Florensky (2010), Réau (1996) e Vernant (1990; 2007) notaram que as obras iconográficas pareciam uma forma de linguagem codificada pelas cores e formas, que falavam não exclusivamente dos dogmas cristãos, mas também das mentalidades que direcionavam o cotidiano da nobreza bizantina.

Assim, Teologia e História deram-se conta de que as problemáticas levantadas pela Iconografia ou pela História acerca das Imagens no período Bizantino, ao zelar pelo ofício de ensinar e investigar, decodificavam os saberes a partir de um núcleo comum: a organização estética e a composição plural das figuras. Era, portanto, dentro de uma contextualização interdisciplinar que o conteúdo relativo às imagens cristãs bizantinas ou aos ícones e assuntos correlatos a eles deveriam ser estudados. Isto porque se atentou ao fato de os saberes teológicos terem sido também desdobramentos da interferência humana sobre assuntos espinhosos para as Igrejas da época e que à História também interessavam. A historiografia percebeu que temas de cunho teológico deixavam de ser exclusivos dos profissionais de uma fé instituída para se tornarem abertos às análises de outros campos do conhecimento e de outras especificidades, especialmente as da História da Arte e da História das Imagens, que trabalhavam criticamente as diversas modalidades de fontes visuais.

Partindo da premissa de que as imagens bizantinas foram construídas socialmente em relação ao um modo de vida do período bizantino, a História os credencia como fontes plausíveis, desde que sejam capazes de mobilizar as problematizações históricas (MENEZES, 2012). Porque as imagens carregam um dizer (GRUZINSKI, 1990) e facilitam o ingresso de informações sobre o período Medieval, este artigo procura explicitar, a partir de um ícone bizantino mariano, as convenções nele inscritas, o que permite adentrar no domínio da História bizantina, com seus pensadores e teóricos. O viés prático dos conteúdos iconográficos do Império Romano do Oriente permite inquirir que os ícones não são apenas ilustrações de cunho religioso, mas formas de representação, como atestam Jacques Le Goff e Jean-Claude Schmitt (2017). Eles eram utilizados como veículos e transmissores de mentalidades e saberes e, por essa razão, são analisados, atualmente, sob o crivo das epistemes e de hermenêuticas tanto da Teologia quanto da História. Por 
isso, para a análise dos ícones bizantinos, tanto uma como a outra buscam nos dogmas cristãos, na patrística, nas escrituras canônicas e nos evangelhos apócrifos as fontes e as justificativas para a análise das imagens no período Medieval (RÉAU, 1996; BECKWITH, 2007).

\section{Iconografia Bizantina, Teologia e História: contribuições recíprocas}

A história do Império Bizantino não pode se limitar apenas a um inventário e a uma análise sobre o movimento de cristianização do Império Romano Oriental nos quais se fixou a experiência e o entendimento da profissão de um modo de crer em que os ícones tinham capital importância (VERNANT, 2007). Fugindo à narração de curiosidades e à mera propagação da arte iconográfica, o uso das imagens bizantinas na Historiografia busca articular os saberes das especificidades da Teologia dogmática Oriental à crítica de toda e qualquer fonte de que se servem as pesquisas. Verifica-se, então, que o uso das imagens na composição de narrativas encerra-se dentro de um contexto de colaboração recíproca entre a historicidade visual e os cânones de uma teologia que foi se modelando até o século $X$, através dos Concílios.

A Igreja que vivia da experiência e do testemunho, passava a alicerçar suas certezas também na razão, teoremas, conceitos, formulações dogmáticas, até mesmo para explicar a aliança com o Império. A partir de então, a Igreja cristã deixava de ser excluída para ser recepcionada pela corte e dela ganhar o status, indumentária, signos e aparatos régios, conservados até o momento presente nas Igrejas cristãs Orientais católicas e ortodoxas, ainda que sob justificativas de novos critérios e hermenêuticas teológicas. Se de um lado, a incorporação de insígnias próprias da simbologia e do poder imperial, presentes nos ritos e cerimônias religiosas desenhavam e organizavam os modos de ser de uma igreja que se servia do poderio para se legitimar, de outro, o Império apropriava-se do capital simbólico e do conjunto de dispositivos imagéticos e materiais de poder (divino) para legitimar e justificar muitos de seus mandos. Essa cooperação acumulativa e associativa resulta na ultrapassagem daquilo que está aparentemente representado na própria figura para se atentar à polissemia das 
apreensões da imagem dentro do contexto plural de conhecimentos. Importante observar que a utilização da imagem no construto de um saber historiográfico não se constitui em oposição às formas outras de narrativas; é uma maneira colaborativa de se construir a História.

Se, no dizer de Rüsen (2001), a historiografia é a materialidade textual da História, o ícone bizantino na Teologia oriental, compreendido qual um texto dogmático, cientifica igualmente pensamentos e inteira saberes que também à História interessam. Os registros iconográficos aos olhos da História, então tomados como fontes visuais, instituem-se desenhos de uma experiência humana abertos aos crivos e às atribuições de sentido. Nessa perspectiva, compreender a imagem iconográfica como fonte que se deixa arguir é tentar entender a relação possível entre História e a estética religiosa. Se uma imagem comunica algo, o saber que dela provém não deve ser menosprezado porque, segundo Antoine Prost (2008), toda imagem auxilia na construção da própria narrativa historiográfica.

Além desta conformidade, torna-se fundamental lembrar que, ainda que se utilize de autores que tratem em suas pesquisas da análise das imagens, as teorias e métodos usados para compor um saber iconográfico estarão também atentos aos da própria Teologia cristã oriental. Exemplo disso é pensar sobre o dogma cristão acerca de Maria, mãe de Jesus de Nazaré, como a Mãe de Deus, ou seja, a Orotóxoৎ, estabelecido por meio do decreto promulgado em 431, na cidade de Éfeso (atual Esmirna, Turquia). Este decreto iniciou uma discussão entre bispos gregos e siríacos que se estendeu durante séculos. O embate fundamentou-se na dúvida de que, se Jesus era de fato humano, deveria nascer de uma mulher, sem que esse fato pudesse, outrossim, diminuir sua natureza divina. A resposta a esse impasse encerrou-se quando se buscou fundamentos teológicos, bíblicos e filosóficos que credenciaram a aclamação da mãe de Jesus como

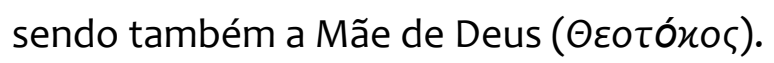

É por essa razão que, sem um conhecimento prévio dessa Teologia, a análise do

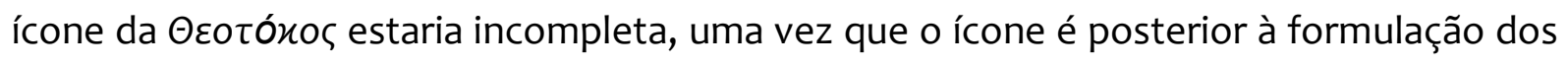
dogmas (ROMANINI, 2000, p. 750). É sempre salutar lembrar que não se trata de substituir um conhecimento pelo outro, mas de se servir, quando possível, de uma 
abordagem teórico-metodológica para a elaboração de narrativas comungantes, multidisciplinares e associativas entre saberes de cunho teológico e historiográfico. Se, para a Teologia, as imagens, por vezes, se impõem, fazendo calar as palavras escritas e os textos bem estruturados, para a História, no entanto, as palavras continuam a ter peso, o escrito continua a ter lugar cativo e, por isso, não pode ser desassociado da necessária apreciação.

Atenta a essas ponderações, a História, a partir da Escola dos Annales, abre-se para outros critérios de análise, possibilitando que uma miríade de novas fontes seja confrontada com as da escrita. Métodos novos de releitura acerca de um acontecido passam a agregar outras maneiras de se construir narrativas, criar e ampliar a formação e a consciência históricas através dos símbolos, percepções e apreensões. O passado também pode, então, ser transfigurado, ressignificado pelos vislumbres dos símbolos religiosos.

Kyrillos Katerelos, pesquisador e professor do Centro de Pesquisa Bizantina da Universidade Aristóteles de Tessalônica, entende que toda imagem é uma expressão material de seu autor. A partir dessa compreensão, pode-se inferir que a relação entre o ícone e seu artífice estabelece os parâmetros de feitura. Portanto, o ícone não possui uma criação autônoma, mas está sujeito aos contextos e às conjunturas socioculturais, às interferências de mentalidades e à sujeição de ideologias (KATERELOS, 2014). O mesmo acontece com a devoção às imagens sagradas. Segundo a Teologia cristã oriental, aquilo que foi representado originalmente no ícone deveria ser perpetuado e mantido através do tempo. Contudo, a História desfaz essa aspiração, porquanto ensina que as experiências do passado devem ser refletidas, debatidas, reconfiguradas pelas novas sensibilidades epistemológicas e novos deslocamentos e investimentos teóricos. Refletir sobre a devoção, mais do que sobre a criação ou escrita de um ícone, reveste-se de especial relevância por fornecer substratos para se entender como os descendentes da cultura religiosa bizantina ainda atribuem sentidos às imagens e como esse entendimento repercute para se pensar historicamente os herdeiros do bizantinismo em países da diáspora. 


\section{A cultura visual bizantina no Brasil: do Medievo às comunidades imigradas}

Passados mais de 50 anos do Concílio Vaticano II, poucos ainda são os cristãos de tradição latina que conhecem as Igrejas bizantinas (ou Igrejas Orientais Católicas e Ortodoxas), suas origens, estrutura hierárquica, liturgias, herança cultural e iconográfica etc. Tal desconhecimento chega, em alguns casos, a produzir situações de estranhamentos, especialmente naqueles lugares onde as duas tradições precisam conviver mais proximamente e compartilhar territórios pastorais.

As duas grandes tradições bizantinas (grega e eslava) das igrejas cristãs Orientais começaram a chegar ao Brasil com as levas de imigrantes, no advento da República e, de modo mais reiterado, após as duas grandes Guerras Mundiais. Essas igrejas, estabelecidas primeiramente nas regiões Sudeste e Sul do país, foram por muitas décadas o centro articulador e garantidor do depósito cultural bizantino das etnias imigradas para as grandes e pequenas cidades da diáspora (São Paulo - SP, Rio de Janeiro - RJ, Vitória - ES, Curitiba - PR, Papanduva - SC, Porto Alegre - RS). Além do idioma, culinária e danças, nessas cidades de recepção e estabelecimentos, o modo de se relacionar com o Transcendente era igualmente preservado, transmitido e tomado como elemento identificador de um modo de ser cristão. Ademais, a religião entre os cristãos orientais sempre ocupou um espaço expressivo no compósito cultural das comunidades imigradas para o Brasil. Os rituais, celebrações, as indumentárias, os ícones, as imagens religiosas e práticas devocionais mantiveram evidente, de modo efetivo, o modo de as comunidades imigradas se compreenderem e se entenderem como pertencentes a um grupo diferenciado de cristãos, em espaços públicos e privados. Dentro ou fora de suas casas, no interior ou no exterior das igrejas, os cristãos orientais bizantinos que imigraram para o Brasil faziam dos ícones, mais do que um engenho capaz de salvaguardar um modo de crer, estandartes que aludem a um pertencimento religioso e instrumentos de memória coletiva ancorados pelas expressões visuais.

Para os cristãos imigrantes, de vertente grega e eslava, a cultura religiosa, sobretudo a dos ícones, não era apenas uma convenção, mas um modo de afirmação de uma étnica fortemente ligada ao pertencimento religioso. Como as fotografias, os ícones, 
portanto, eram também conservados quais artefatos de memória, veículos da manutenção de pertencimentos. Desse modo, o respeito aos ícones deixa de ser explicado meramente por um costume cultural, mas compreendido qual materialidade de uma fé legitimada pelos cânones, expressa pelas cores, formas e dizeres teologais.

Para a História das Imagens, os ícones bizantinos não são apenas objetos que prospectam ou encerram informações, mas receptáculos prenhes de fontes ou de pistas que podem levar ao desnude de um saber decodificado pela Teologia, por exemplo. Desse modo, a História que se ocupa da leitura das imagens deverá igualmente acercar-se desse campo investigativo para lograr êxito em suas ponderações quando for se circundar dos ícones bizantinos. Ao sair de si mesma, ao extrapolar as fronteiras da zona de conforto, ao superar os limites de suas carências, a História poderá observar as imagens religiosas bizantinas como documentos fiáveis, passíveis de análises, interpretações, arguições. Isso pode ser explicado pelo fato de as religiosidades e seus artefatos imagéticos e ritualísticos repercutirem no imaginário social e no agir coletivo tendo como referência o sagrado, a transcendência. Detentores de um saber, os ícones passam então a ser considerados um invento interpretativo normatizador somado a outros modos de hermenêutica do conhecimento humano.

Nessa mesma linha de reflexão, Evdokimov (1990) observa que, para as comunidades de cristãos orientais imigrantes, os ícones podem, do mesmo modo, ser fontes para a compreensão de grupos que se reconhecem pelo apreço a uma cultura religiosa desenhada a partir de pressupostos dogmáticos. Pelo culto às imagens, o autor percebe a centralidade que as instituições religiosas bizantinas ocupam quando da recriação de laços por parte dos imigrados com o país de origem.

Nesse sentido, para as comunidades russas, ucranianas e gregas imigradas para o Brasil, os ícones materializavam a dimensão religiosa de um pertencimento explicado por premissas culturais e por razões que fogem do caráter puramente físico, material, lógico, explicável somente pela razão. Se por um lado, o ícone bizantino representava uma maneira de compreender o mundo, de outra, auxiliava o cristão oriental imigrado a compreender e interpretar, pela lógica do mundo visível, o desdobramento de sua fé 
espargida na cotidianidade, na particularidade dos afazeres e compromissos de natureza relacional, e o seu papel integrador na comunidade professante.

A fé institucionalizada e celebrada se reverberava pelo conjunto de imagens que ora passeava nas procissões, ora ficava imóvel nos nichos ou oratórios das casas. Paradoxalmente, a visibilidade do ícone reportava para a invisibilidade das coisas divinas, das realidades transcendentes, dos referentes de natureza sagrada, explicada somente pelo tributo de uma crença. Observa-se, portanto, que as devoções e as práticas devocionais do cristianismo oriental bizantino configuravam-se elemento estruturante da identidade coletiva dos imigrantes, ainda que fosse, às vezes, reconfigurada quando defrontada por outras espiritualidades, outras manifestações de fé ocidentais.

Entre tantas imagens, os ícones marianos eram os que mais significavam e ocupavam lugares de devoção entre os cristãos orientais imigrados (TAMANINI, 2017). Mas essa devoção nem sempre era anunciada ou propagandeada, o que fazia gerar dúvidas sobre o lugar de Maria na religiosidade dos cristãos bizantinos. Ainda continua comum que se surpreendam os cristãos latinos ao descobrir que os cristãos orientais nutram por aquela a quem designam de Nossa Senhora uma aceitação tão forte quando a deles.

Isso porque a compreensão mariológica na tradição oriental, notadamente a bizantina, foi se desenvolvendo de modo distinto do ambiente teológico da Igreja latina. Enquanto a primeira fundamenta a devoção a Maria através do respeito aos dogmas instituídos até o século $X$, a segunda acresce à observância dogmática as devoções populares. Na Teologia cristã de vertente ortodoxa, a fundamentação da devoção ao ícone é cristológica, isto é, "em toda imagem iconografada transparece os fundamentos de uma fé professante na pessoa de Jesus Cristo (FELMY, 2002, p. 116). Soma-se a essa ponderação o pensamento teológico mariano de Uspenski que adverte: "numa época profundamente marcada pelo visual, é mister, adverte, prestar mais atenção à vista, dirigir-se à contemplação da imagem" (USPENSKI, 2013, p. 480).

A chamada de atenção desses teólogos facilita compreender como os cristãos imigrados representavam sua crença também pela hegemonização de sentidos decorrentes de uma memória religiosa coletiva. Aproximar-se do sentido e conteúdo 
dialógicos em relação à devoção ao ícone bizantino, para observar que o passado e a cultura religiosa dos imigrantes podem ser outra vez recontados e reformulados em cada presente, torna-se uma adequada metodologia de pesquisa. Observa-se aqui uma colaboração entre a História e a Teologia, entre os saberes instituídos de duas áreas do conhecimento que procuram entender, de acordo com seus respectivos pressupostos teóricos, o percurso, a atribuição de sentidos e a manutenção da devoção dos imigrantes cristãos bizantinos aos ícones, no decurso de um tempo.

\section{O ícone de Maria na devoção bizantina: da técnica aos nomes e significados}

Desde as primeiras representações da Oeotóxos (que remontam aos fins do II século, nas catacumbas de Priscila, e, especialmente, a partir do Concílio Ecumênico de Éfeso), as imagens da Mãe de Deus se multiplicaram, de muitos modos e estilos (CARRASCO TERRIZA, 1982, p. 578). Passa-se, então, a discorrer sobre o lugar da imagem na narrativa historiográfica bizantina, sob o aspecto estreitamente relacionado à iconografia mariana. Tal intento é justificado pelo entendimento de que a iconografia bizantina está intimamente associada à História das imagens religiosas e à prática de fé

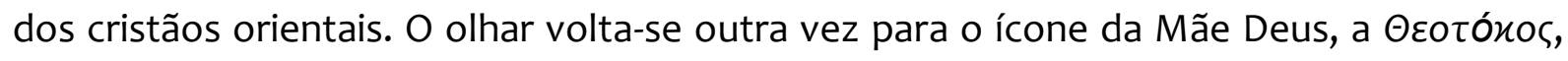
procurando os rastros de sua feitura e as concepções teologais dentro dos contextos em que estava inserida, trazidos para o Brasil com a chegada dos imigrantes eslavos e gregos.

Falar do culto a Maria entre os cristãos orientais faz lembrar os incontáveis ícones relacionados a Nossa Senhora, presentes nas igrejas e nos lares. Desde que a iconografia começou a florescer, nos primeiros séculos da Igreja cristã, Maria ocupa um lugar só comparável ao de Cristo na fé eclesial do Oriente. Os diversos ícones da Orotóxoৎ apresentam aspectos diferenciados entre si e, por isso, fogem do padrão dos outros santos retratados no Império Romano Oriental por causa da densidade teológica da pessoa de Maria. Entretanto, uma caraterística não se altera: a Mãe de Deus sempre é apresentada em sua majestática hierarquia, como a mãe do soberano, por isso sempre rainha, altiva, materna (MAGUIRE, 2000). 
A iconografia bizantina do Período Medieval: percepções acerca das imagens religiosas para a pesquisa de História

Paulo Augusto Tamanini

Na tradição cristã oriental, o ícone de Maria não é somente o ícone da Virgem, mas a inscrição do mistério da encarnação, a realidade da Igreja, a comunhão entre o humano e o divino (TONIOLO, 2003). Ademais, é consenso afirmar entre os iconólogos que o cerne teológico, a razão de ser do ícone da Oeotóxos (Mãe de Deus) é deixar transparecer e enaltecer a maternidade divina, a encarnação; a Teologia bizantina ensina que a Mãe de Deus, unida profundamente a seu Filho, mais que um instrumento passivo ou circunstancial na obra da redenção do homem, manifesta a dimensão humana da

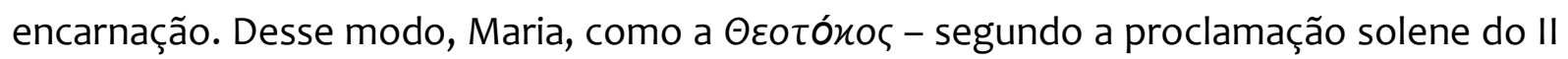
Concílio Ecumênico de Éfeso -, preside com Cristo o destino do mundo e, como tal, sua imagem ocupa o primeiro lugar, depois da imagem de Cristo, na vida das Igrejas orientais, na fé eclesial que é expressada na piedade litúrgica, na arte sagrada, na literatura e no canto religioso (TSELENGIDIS, 1984).

Desde então, o desenho do ícone segue normas precisas, que foram elaboradas pelos monges gregos e deram origem aos cânones, às regras de como se fazer.
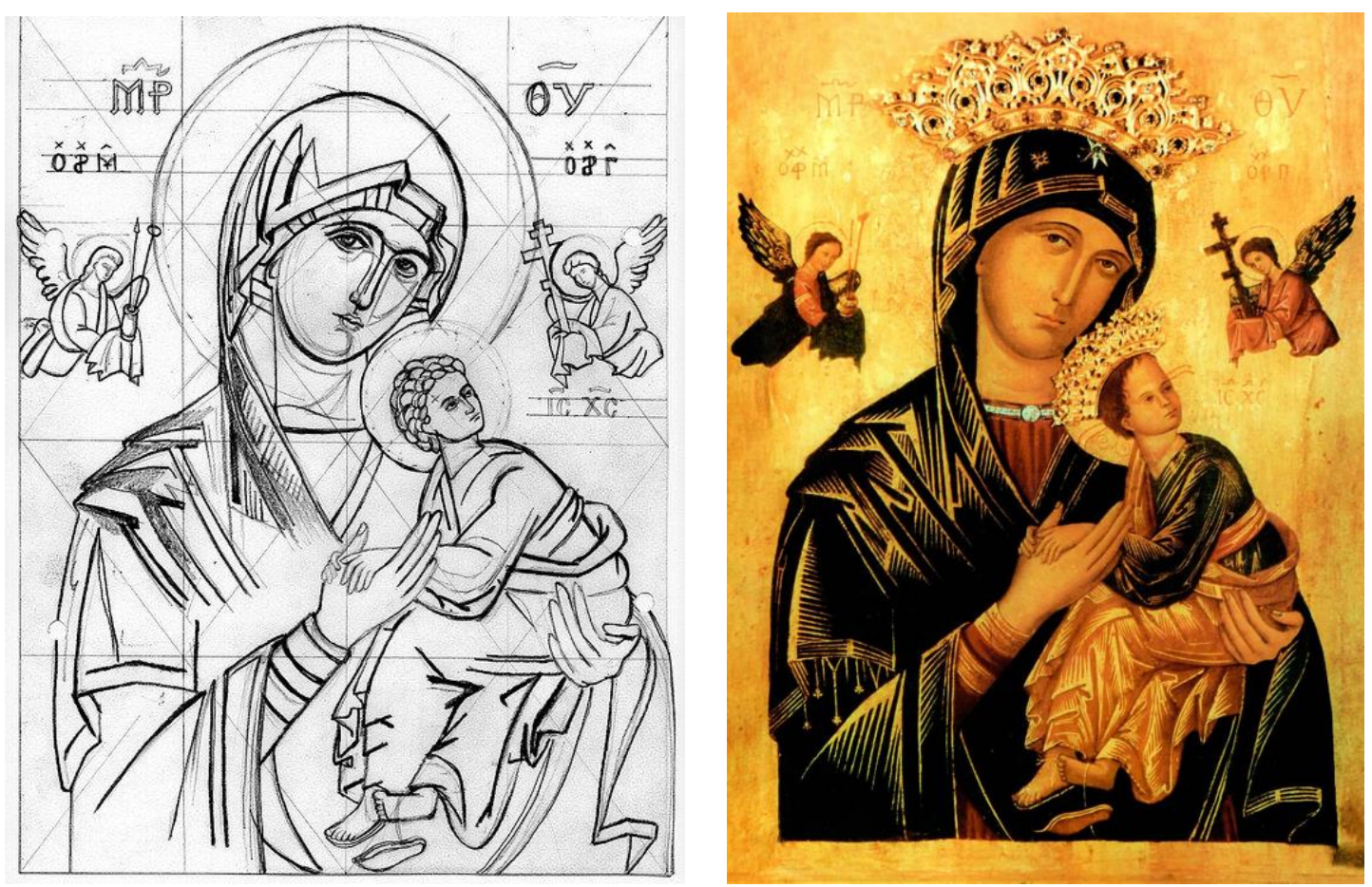

Figura 1 Estrutura geométrica do ícone de Maria do Perpétuo Socorro

Século XI (USPENSKI, 2013, p. 47). 
A figura à esquerda mostra a composição de um ícone à Virgem Maria, obediente às estruturas geométricas da escola monacal grega que estabelecem a harmonia entre os diversos elementos. Nesse arquétipo, círculos interseccionados orientam a inteireza de toda a imagem. É possível observar que, quando da comparação com o ícone finalizado (à direita), a figura central está desnuda de todos os atributos imperiais. Isto porque o protótipo recebeu, no decorrer dos séculos XII e XIII, as cores e vestimentas do Império Bizantino, em conformidade com os cânones aprovados pelos Concílios (USPENSKI, 2013, p. 47).

Segundo a tradição bizantina, a feitura do ícone é precedida por momentos de orações e jejuns intensos que lapidam as mãos, mente e técnica do iconógrafo. Após esse período de preparação espiritual, Ribichini (2007) lembra que ainda são necessários alguns cuidados: a escolha da madeira que deve ser lisa e estar sem nenhuma umidade. $O$ costume grego apregoa que todo ícone é escrito sobre lâminas de madeira e que as derivações (ícones pintados sobre pedras, paredes de tijolos, cascas de ovos, tecidos ou papel) não deveriam receber o nome de ícone. Contudo, as escolas iconográficas dos ramos grego ou eslavo, desde meados do século $\mathrm{XV}$, reconsideraram essa obrigação (RIBICHINI, 2007, p. 128).

Depois do material escolhido, o saber-fazer da iconografia impõe que seja preparado um fundo branco (chamado de levkas). A técnica do levkas já era conhecida dos egípcios, tendo sido encontrada em vários sarcófagos, sendo readaptada para a arte grega. A principal função dessa técnica é a de refletir de modo comedido a luz que incide sobre a imagem, na qual as cores possam se conformar à totalidade da figura. Geralmente, a levkas na tradição grega é uma solução preparada com pó de gesso ou com algum produto colante extraído de ovos, espinha de peixe ou resina de arvores. $\mathrm{Na}$ tradição eslava, seguida pelos ucranianos de Curitiba, a levkas pode ser preparada também com resina de pinheiro. Posteriormente ao jejum, à escolha da madeira e à preparação da levkas e, após se escrever a figura, as regras iconográficas prescrevem o correto uso das cores, cada qual com seu significado teológico e profundidade hermenêutica. 
Embora a confecção dos ícones eslavos, árabes e coptas etíopes obedeçam à forma e cores advindas da teologia grega, foi o leste europeu que mais adaptou algumas das características dessa arte religiosa. Muitos dos ícones eslavos, por exemplo, não carregam mais as letras do idioma grego, sendo substituídas pelo cirílico, a linguagem teológica e da iconografia eslava, do qual as comunidades étnicas ucranianas aportadas no Brasil desde o século XIX são herdeiras. Logo, o lugar, como já frisado, não é apenas um registro estéril; aqui soube se impor, ditando maneiras diferentes de se obedecer às regras, costumes, sem ser despótico. Alguns desses modelos que chegaram ao Brasil com a imigração de cristãos orientais permitem classificar os ícones marianos do ponto de vista tipológico, com suas cedências e adaptações.

Para o objetivo deste subitem, considera-se suficiente apresentar as principais

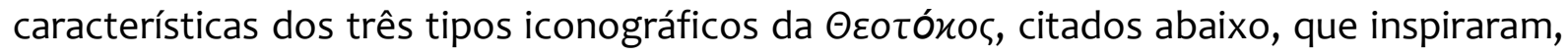
no decorrer dos séculos, uma infinidade de outras variantes, cuja classificação seria uma árdua, senão impossível tarefa a ser desenvolvida. Estas, tanto no ambiente cristão do Oriente como do Ocidente, foram ganhando traços e cores peculiares em determinadas culturas, regiões, costumes. A título de exemplo, no que diz respeito à variedade, só o calendário da Igreja Russa, onde a iconografia da Virgem está muito desenvolvida, mencionam-se 260 tipos de ícones marianos sob 700 denominações diferentes (USPENSKI, 2013, p. 58).

Dentre as características básicas comuns dos ícones marianos, destacam-se os fundamentos que sustentam as verdades da fé cristã: a) o dogma da virgindade da Mãe de Deus - antes, durante e depois do parto -, que é representada por três pequenas estrelas: duas sobre os ombros e uma sobre a testa (frontal); e, b) o dogma da

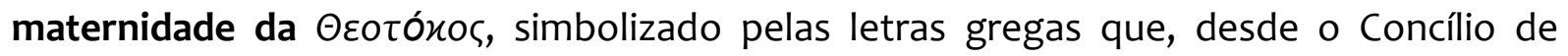
Éfeso, passaram a ser usadas nos ícones da Virgem (MP ӨY). Tais letras são a abreviação de H MHTEPA TOY OEOY - A Mãe de Deus - que protagoniza a importância de Maria de Nazaré na história do Cristianismo.

Em síntese, observa também Uspenski (2013) que os ícones da Virgem se distinguem daqueles dos demais santos e anjos, tanto pela variedade da sua tipologia iconográfica quanto pela sua natureza explicativa: Maria refulge como 1) a Elleousa - Mãe 
de Ternura; 2) a Orante - intercessora, suplicante; e, 3) a verdadeira Odighitria - aquela que indica o Caminho e guia seus filhos enquanto peregrinam nesta existência rumo ao futuro escatológico. Os três tipos mencionados inspiraram uma variedade de modelos iconográficos marianos, com títulos e apelativos que os vincularam a diferentes tradições, culturas, povoando os calendários de festas locais, santuários e as casas de seus devotos.

\section{Conclusão}

A atual historiografia compreende a imagem como portadora de significados partilhados, como um documento, cujas propriedades técnicas, estilísticas e iconográficas remetem a um modo de percepção que molda as narrativas (AUGE, 1997). Nessa perspectiva, pensar a relação entre História e Imagem é pensar também em intertextualidade, representações e releituras de uma realidade codificada pelos formatos, cores e nuances. Por isso, ao analisar os materiais imagéticos, os historiadores se sentem compromissados em detectar as percepções, as mentalidades e as convenções que permitem adentrar no universo dos símbolos, dos sinais, das mensagens e das alegorias que se presentificam em um determinado tempo.

Dessa forma, o passado pode ser melhor desvendado em algumas de suas nuances, compreendido em aspectos singulares e relidos dentro de um panorama multidisciplinar. As imagens religiosas também são fontes das quais a História se serve na construção de enredos e narrativas. Não se restringem apenas a informar, anunciar, dizer, a partir de um só campo interpretativo racional. Brotadas da introspecção, remetem ao transcendente, ao místico, àquilo que não se pode revelar a priori, apenas ao experimentar. As formas, as cores, os vocábulos fantasiados de tinta escrevem o formalismo místico de uma mensagem, inspiram relatos, provocam narrativas, emitem signos estéreis de deduções apenas mundanas. Transportam signos indizíveis que, a princípio, para a razão parecem estranhos, mas que são simbioticamente assimilados pela alma que os interpreta assim que os vê ou sente. Logo, precisam de profissionais que decodifiquem seus signos! 
Como na História, coube também à Teologia revisar ou reconsiderar conceitos, usar de linguagens coetâneas e reinterpretar as fontes à luz das demandas de atuais contextos, tendo o cuidado, no entanto, de não cair em casuísmos ou modismos. Então, é preciso pontuar que a Teologia, como outras áreas do saber, ainda que não esteja cega às realidades de cada tempo, não é de todo instável, uma área de saber cambaleante em seus fundamentos, que se deixa seduzir facilmente por apelos da hora ou pelas inconstâncias de épocas. Tenta, ao contrário, acalentar as inquietações, sem perder seu prumo, porque estruturada e fundamentada pelas verdades conciliares, promulgadas como inalteráveis, incontestes e perenes. O olhar que teologiza sobre os diversos temas deve enriquecer o próprio campo de conhecimento, uma vez que é através das questões levantadas no tempo presente que se mostra e traduz o entendimento da fé, a forma como é lido e entendido o Cristianismo (RUIZ MONTEJO, 1991).

Os ícones bizantinos marianos trazem um saber e são contributos da História de Bizâncio e do Medievo. Períodos estes que a Historiografia atual retoma e garimpa, nas águas turbulentas daquele tempo que se foi, os rudimentos de um fato, de um texto ou de uma arte. A arte bizantina não é somente a arte de uma religião. É a materialidade de um saber que norteou um império, que deu fundamentos a uma nova religião e que, posteriormente, se alastrou pelos quatro cantos do orbe. O ícone também revela o modo como o conhecimento adquirido ganhou perenidade e registros de documentação. As imagens pensadas em Bizâncio se juntam aos textos, aos decretos, e ganham o status de preciosa documentação aberta às pesquisas. Engana-se quem pensa que a arte cristã bizantina se restringe a reverberar unicamente os dados de uma religião nascente do Império Romano no Oriente. Em cada detalhe do ícone mariano, por exemplo, a História amalgamada à Teologia busca a crítica e a documentação de uma obra, deixando pistas para possíveis hermenêuticas explicadas pelo método analítico da cientificidade. Logo, muito do estatuto da História, da Filosofia ou da Teologia fazem morada circunscrita em uma aparente tela ou madeira em que um ícone bizantino se deixa desnudar. Entender os pressupostos daquela crença que observava no ícone a concretude da fé é tentar compreender como homens e mulheres buscavam respostas a tantas perguntas. Muitas delas até hoje vagam procurando ser aquilatadas. 
Os ícones obedecem aos cânones, às regras, às normas para sua feitura, desde o século IV. Ainda que tenham justificativas teológicas compreensíveis, revelam uma maneira de se lidar com o transcendente, de se perpetuar o bizantinismo que extrapolou os marcos do Medievo, através da contemplação da beleza. O ícone bizantino, para além da arte estética e sutilezas dos dogmas cristãos, mostra um percurso de formulações de saberes calcado em acordos legitimados pela consonância dos pares. O lugar, no entanto, esse quase que despercebido ponto geográfico, faz observar em quais pressupostos estão alicerçadas a tradição e as permanências das regras na composição de um ícone, bem como a forma como ainda produz sentidos e são compartilhadas as experiências e percepções.

A alternância do idioma grego pelo ciŕlico ou a troca de resinas de peixe ou de ovo pela de pinheiro, na técnica de se escrever um ícone, por exemplo, evidenciam que o lugar impõe suas condições para se manter um costume, uma arte, um modo de se fazer. Com o uso do novo idioma, a composição dos ícones bizantinos a despeito da dimensão religiosa, orbita os contornos mais precisos de referência étnica e de pertencimento.

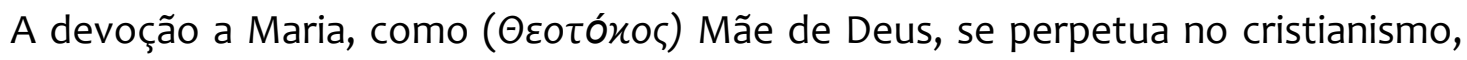
auxiliada pela Escritura, pela força dos dogmas e pela contemplação das imagens religiosas que, em cada lugar, recebem um nome e experienciam diferentes modos de percepção e de devoção. Os ícones marianos mostram o quanto ao redor das imagens religiosas gravitam um conhecimento, um saber específico e que não prescinde de historicidade. Estudar as comunidades eslavas e gregas imigradas para o Brasil, quais herdeiras da devoção e perpetuação de respeito às imagens religiosas bizantinas, permite pensar os ícones para além do vínculo religioso e ressaltar o poder que eles têm de continuar a produzir domínios, encantamentos e sentidos. Os ícones, dos quais os ortodoxos e católicos de rito oriental acreditam ser os guardiães, parecem então carregar uma mensagem e uma maneira de se relacionar com o sagrado. $E$, por mais que não seja decifrável pelas novas gerações, continuam a pontificar um saber e um percurso de códigos que foram advindos de uma regularidade.

Mesmo que o caldo de devoção religiosa seja frequentemente moldado pelas mediações simbólicas que circundam o lugar em que os orientais aportaram e ainda 
A iconografia bizantina do Período Medieval: percepções acerca das imagens religiosas para a pesquisa de História

Paulo Augusto Tamanini

vivem, indica um fiel cristão oriental que tenta experimentar Deus à sua maneira.

Redesenhadas na tela dos espaços de acolhida, a face e a identificação étnico-religiosa dos herdeiros desse inventário cultural passaram a ganhar novos tons e um colorido que traduz uma liberdade de escolha e de profissão de fé e pertencimento religioso. Longe de ser uma descontinuidade, os cristãos bizantinos, a um modo condizente ao contexto do espaço, atualmente trocam suas experiências, sem maiores revezes. Se de um lado, o lugar de acolhimento de cristãos orientais tentava ditar seu ritmo e impor a readequação cultural daqueles que nele procuraram aconchego, por outro, os ortodoxos e católicos orientais deixaram também suas marcas, sabendo com maestria conciliar sua herança cultural com as novidades trazidas pelo urbano, mapeando relações com a alteridade. 


\section{Referências}

AUGE, Marc. La Guerre des rêves: exercices d'ethno-fiction. Paris: Editions du Seuil, 1997.

BECKWITH, John. Arte paleocristiano y bizantino. Madrid: Cátedra, 2007.

CARRASCO TERRIZA, Manuel Jesus. Aspectos cristológicos en la iconografía de la Theotokos. In: MATEO-SECO, Lucas F. Cristo. Hijo de Dios y redentor del hombre. Pamplona: Universidade de Navarra, 1982.

EVDOKMOV, Paul. Teologia da beleza: a arte do ícone. Milão: Mondadori, 1990.

FELMY, Karl Christian. Teología ortodoxa actual. Salamanca: Sígueme, 2002.

FLORENSKY, Pável. La columna y el fundamento de la verdad: ensayo de teodicea ortodoxa en doce cartas. Salamanca: Sígueme, 2010.

GRUZINSKI, Serge. La guerre des imagens. Paris: Fayard, 1990.

KATERELOS, Kyrillos. L'apport de Nicolas Cabasilas à l'ecclésiologie à partir de la théologie des mystères. Strasbourg: Université de Strasbourg, 2014.

LE GOFF, Jacques; SCHMITT, Jean-Claude. Dicionário analítico do ocidente medieval. São Paulo: Editora UNESP, 2017.

MAGUIRE, Henry. The icons of their bodies: saints and their images in Byzantium. Princeton: Princeton University Press, 2000.

MENEZES, Ulpiano Bezerra de. História e imagem: iconografia/iconologia e além. In.: CARDOSO, Ciro; VAINFAS, Ronaldo (Orgs.). Novos domínios da história. Rio de Janeiro: Elsevier, 2012.

PROST, Antoine. Doze lições sobre a história. Belo Horizonte: Autêntica, 2008.

RÉAU, Louis. Iconografía del arte cristiano: iconografía de la biblia, nuevo testamento. Barcelona: Ediciones del Serbal, 1996.

RIBICHINI, Sérgio. Sulle tracce del mito: dei ed eroi greci, tra archeologia e storia delle religioni. Novara: De Agostini, 2007.

ROMANINI, Angiola Maria. Enciclopedia dell'arte medievale. Roma: Istituto della Enciclopedia Italiana, 2000.

RUIZ MONTEJO, Inés. El nacimiento de la iconografía Cristiana. Cuadernos de Arte e Iconografía, v. IV, n. 7, 1991, p. 21-32.

RÜSEN, J. Razão da história: fundamentos da ciência histórica. Brasília: Editora Universidade de Brasília, 2001. 
SCHMITT., Jean-Claude. Le Corps, les rites, les rêves, le temps:essais d'anthropologie médiévale. Paris: Editions Gallimard, 2001.

USPENSKI, Leonid. Teología del ícone. Salamanca: Ediciones Sígueme, 2013.

TAMANINI, Paulo Augusto. A prece ucraniana na pressa da cidade: as renegociações das práticas religiosas ucranianas nos espaços da cidade de Curitiba a partir de 1960. Curitiba: Editora CRV, 2017.

TSELENGIDIS, Dimitrius. The theology of the image and its anthropological importance. Thessaloniki, 1984 .

TONIOLO, Ermanno M. Contemplare Maria attraverso l'immagine: Oriente e Occidente. Roma: Centro di Cultura Mariana, 2003.

VERNANT, Jean-Pierre. Mito e pensamento entre os gregos: estudos de psicologia histórico. Paris: La Découverte, 2007.

VERNANT, Jean-Pierre. Figures, idoles, masques. Paris: Julliard, 1990. revistapercursos@gmail.com 